https://dx.doi.org/10.4314/ijs.v21i3.9

Ife Journal of Science vol. 21, no. 3 (2019)

\title{
WATER QUALITY OF SOME WATER SOURCES IN IGARRA AND THE ENVIRONS IN AKOKO - EDO, SOUTHERN NIGERIA
}

\author{
Lawani, F. A.* and Dirisu, A. \\ Department of Animal and Environmental Biology, Faculty of Life Sciences, University of Benin, \\ Benin City, P.M.B 1154, Nigeria \\ E-mail for correspondence: francis_afe@yahoo.com,dedonrahman10@yahoo.com
}

(Received: 21 ${ }^{\text {st }}$ April, 2019; Accepted: $4^{\text {th }}$ September, 2019)

\section{ABSTRACT}

Evaluation of the physico-chemical and microbiological characteristics of selected water sources from Igarra and environs in Akoko-Edo, Nigeria was carried out using standard methods. The results obtained for some of the parameters investigated were in the following range: $\mathrm{pH}(4.2-6.8)$, turbidity $(0.01-0.75 \mathrm{NTU})$, conductivity $\left(7.2-196.0 \mu \mathrm{Scm}^{-1}\right)$, dissolved oxygen $\left(3.2-29.2 \mathrm{mgL}^{-1}\right)$, biochemical oxygen demand $\left(0.0-25.6 \mathrm{mgL}^{-1}\right)$, chloride $\left(10.23-106.36 \mathrm{mgL}^{-1}\right)$, calcium $\left(0.0-80.88 \mathrm{mgL}^{-1}\right)$, sulphate $\left(0.0-7.35 \mathrm{mgL}^{-1}\right)$, nitrate $(0.01-8.91 \mathrm{mgL}-$ 1), copper $\left(0.01-1.03 \mathrm{mgL}^{-1}\right)$, zinc $\left(0.0-1.43 \mathrm{mgL}^{-1}\right)$, Iron $\left(0.02-2.30 \mathrm{mgL}^{-1}\right)$ and lead $\left(0.0-0.33 \mathrm{mgL} \mathrm{L}^{-1}\right)$. All samples harboured coliform organisms in numbers that exceeded the WHO standard for drinking water. Ranges of total heterotrophic bacteria (THB) count was $1.0 \times 10^{3}-1.3 \times 10^{4} \mathrm{cfuml}^{-1}$; total heterotrophic fungi (THF) count $1.0 \times 10^{3}-9.0 \times 10^{3} \mathrm{cfuml}^{-1}$; presumptive coliform count $0-2.9 \mathrm{MPN} 100 \mathrm{ml}^{-1}$ and Escherichia coli 0 - 2.7 MPN $100 \mathrm{ml}^{-1}$. This study revealed that magnesium hardness, microbial contamination, and acidity of the water sources which resulted in corrosivity of the water are some of the indicator parameters for Akoko-Edo water quality; and therefore concluded that the water sources were unsuitable for human consumption. Adequate and appropriate treatment of the water prior to consumption to maintain good public health is therefore recommended.

Keywords: Water Quality, Public Health, Coliform, Hardness, Corrosivity

\section{INTRODUCTION}

The majority of the populations in developing countries are not adequately supplied with potable water, and are thereby compelled to use water from sources like shallow wells and boreholes that render the water unsafe for domestic and drinking purposes due to high possibilities of contaminations (WHO, 2006; Dirisu and Olomukoro, 2015). This assertion is a true reflection of the water crisis in Akoko-Edo Local Government Area of Edo State, Nigeria which is located on a rocky geology.

Despite the construction of the Ojirami dam in 1974 that supplied potable pipe-borne water to majority of the towns and villages, its epileptic supply of water in recent times has forced the populace to rely on other sources of water for domestic and drinking purposes regardless of their quality. In many developing countries like Nigeria, unavailability of treated water for drinking and domestic usage has become a critical problem and a matter of great concern to communities that depend on public water supply system (Okonko et al., 2008).
According to Federal Ministry of Health statistics, only about $30 \%$ of Nigerians have access to potable water while the WHO estimated that about 1.5 billion people do not have access to safe drinking water with all the consequences of water borne diseases such as cholera, typhoid, diarrhoea, and dysentery becoming potentially communicable (WHO, 2006). Many of the streams, ponds, springs, hand-dug wells and boreholes in Akoko-Edo are located either too close to locations where corpses are buried and/or septic tanks (soak-away pits) are dug, or around places where they are exposed to other anthropogenic pollution.

Communities which rely on untreated groundwater supply for domestic and agricultural uses are most exposed to the impact of poor water quality (Agbabiaka and Sule, 2010; Akpoveta et al., 2011). No doubt, ensuring access to low cost water supply (improving access to clean water or making access more secure) will improve the people's welfare. During passage through the ground, water dissolves minerals in rocks, collect 
suspended particulate matter, particularly those of organic sources as well as pathogenic microorganisms from faecal matters (Onuh and Isaac, 2009).

The objective of this study was to provide information on the water quality of Igarra and the environs using physico-chemical and microbiological characteristics of the selected water sources, and their suitability for human consumption based on water quality standards of the World Health Organisation (WHO) and Standard Organisation of Nigeria (SON).

\section{MATERIALS AND METHODS \\ Study Area}

Akoko-Edo (Figure 1) is located in the northern part of Edo State, Nigeria with its administrative headquarters (Igarra) at latitude $7^{\circ} 16.9789^{\prime} \mathrm{N}$ and longitude $6^{\circ} 6.134^{\prime} \mathrm{E}$. There are a lot of communities and a few towns that constitute the Local Government Area. Some of the towns include: Okpe, Somorika, Ikpeshi, Ojirami, Uneme-Osu, Ibillo, Ososo, Ijaja. Ogbe, and so forth. The local government has an undulating and elevated topography; and it is endowed with caves, different rock types with diverse shapes and sizes, making it a tourist site yet to be harnessed. It is characterized by two major climatic seasons, dry season from October to May, and rainy season from June to September. The major sources of water in the locality are: streams, rivers, springs, ponds, rock-ponds, boreholes and hand-dug wells. The people are predominantly farmers and miners.

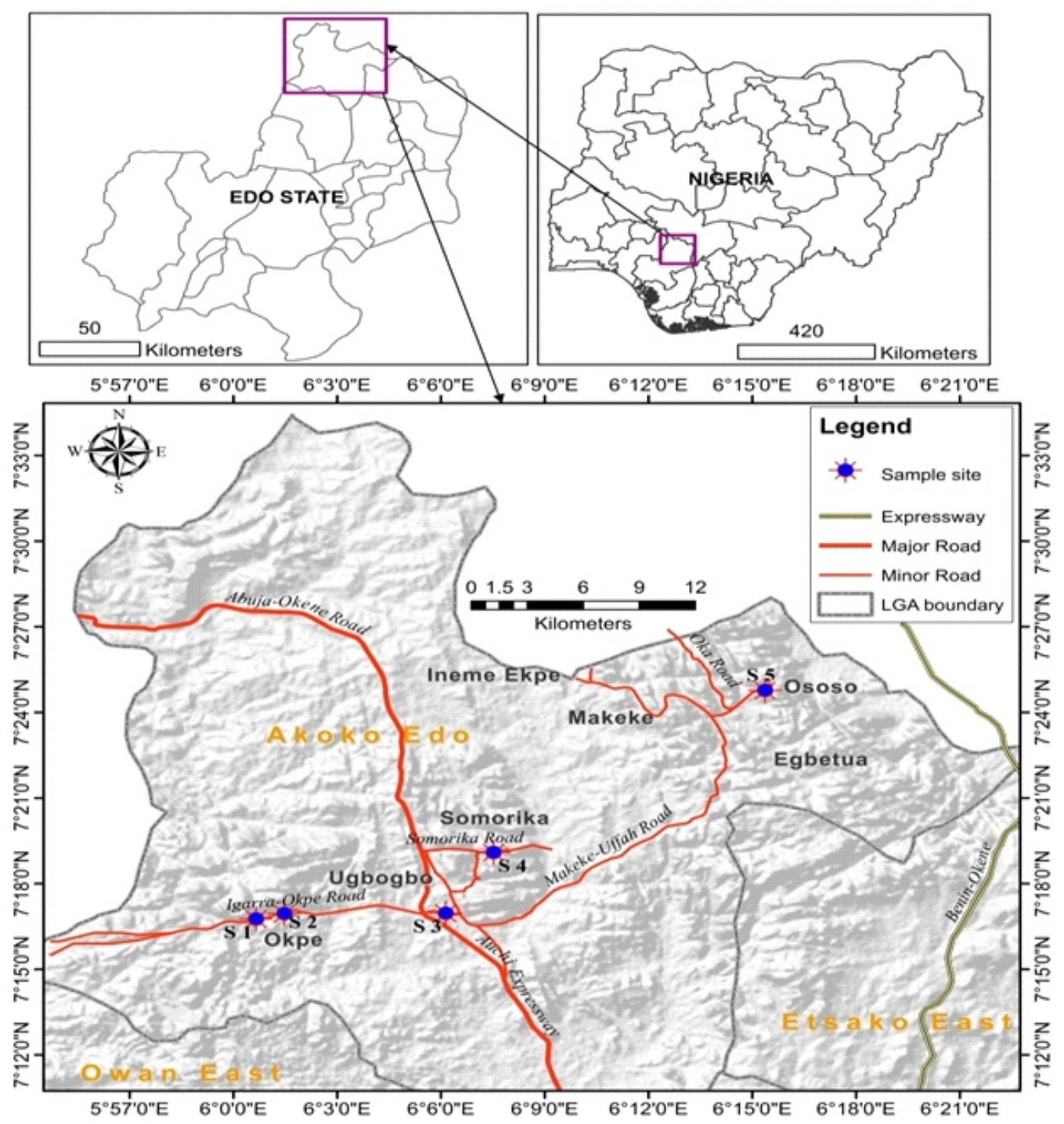

Figure 1: Map of the Study Area 


\section{Sample Collection and Analysis}

Water samples were collected from the spring, pond, borehole, rock-pond and hand-dug well on a monthly interval for a period of eight (8) months, covering dry and wet seasons. Temperature (air and water), pH, electrical conductivity, dissolved oxygen and total dissolved solids were determined in-situ using handheld instrument (Hach pH/Conductivity/TDS meter sense ion 2 Model). Other physicochemical parameters analysed included: turbidity, biochemical oxygen demand, salinity, nitrate, chloride, nitrate, phosphate, sulphate, magnesium, calcium, potassium, sodium, iron, copper, zinc and lead using standard methods as described by APHA (2005). The results obtained were compared with the recommended limits by the World Health Organisation (WHO, 2006) and the Standard Organisation of Nigeria (SON, 2007) prescribed for drinking water. Data obtained were subjected to statistical analysis using a one way analysis of variance (ANOVA), and a Posteriori Duncan Multiple Range (DMR) test was used to determine the source of significant difference recorded among the stations. Water quality index (WQI) was calculated using the weighted arithmetic mean index as described by Yisa and Jimoh (2010) and on the basis of the suitability of the water sources for human consumption using the WHO and SON standards.

\section{Bacteriological Characteristics Determination}

The media (nutrient agar) used for bacteriological analysis were weighed out and prepared according to manufacturers' instructions and directions. The plate count method was used which relies on bacteria growing a colony on a nutrient agar medium, so that the colony becomes visible to the naked eyes and the number of colonies on a plate can be counted. Presumptive coliform count was determined by MacConkey broth; positive result was indicated by acid and gas production on incubation at $37^{\circ} \mathrm{C}$ for 48 hours (Edema et al., 2001). Eosin methylene blue medium was used to determine E. coli; organisms with greenish metallic sheen were indicative of positive results. This was further confirmed by the ability of the organism to ferment lactose at $44{ }^{\circ} \mathrm{C}$. The pour plate technique was used to determine aerobic mesophillic count using standard methods (APHA, 2005).

\section{Estimation of Water Quality Index}

Drinking water quality index (WQI) is intended to provide an easy-to-understand ranking of water quality. It is also a very useful tool for communicating the information on the overall quality of water (Yisa and Jimoh, 2010). In this study, sixteen important parameters were adopted in the calculation of WQI. The parameters include: $\mathrm{pH}$, turbidity, conductivity, total dissolved solid, dissolved oxygen, biochemical oxygen demand, chloride, sulphate, nitrate, magnesium, iron, lead, copper, zinc, E. coli and total coliform count.

Water quality index was calculated using the weighted arithmetic index method as described by Yisa and Jimoh, (2010). The values obtained were compared to the water quality scale (Table 1 ). The different water quality components were multiplied by a weighting factor and then aggregated using simple arithmetic mean (Cude, 2001).

Table 1: Water Quality Index (WQI) and Status of Water Quality

\begin{tabular}{ll}
\hline Water Quality Index Level & Water Quality Status \\
\hline 50 & Excellent water quality \\
$50-100$ & Good water quality \\
$100-200$ & Poor water quality \\
$200-300$ & Very poor water quality \\
$>300$ & Water unsuitable for drinking purposes \\
\hline
\end{tabular}

Source: (Ramakrishniah et al., 2009) 
Quality rating or sub index for the $\mathrm{n}^{\text {th }}$ parameter (Qn) was calculated using the following expression;

$\mathrm{Qn}=100\left(\mathrm{Vn}-\mathrm{V}_{10}\right) /\left(\mathrm{Sn}-\mathrm{V}_{10}\right)$

Where,

Qn = Quality rating of the parameter for a total of $\mathrm{n}$ water quality parameters

$\mathrm{Vn}=$ Actual value of the water quality parameter obtained from laboratory analysis

$\mathrm{V}_{10}=$ Ideal value of that $\mathrm{n}^{\text {th }}$ water quality

parameter in pure water. $V_{10}=0$ for all

parameters, except $\mathrm{pH}$ and $\mathrm{DO}$ which are 7 and

$14.6 \mathrm{mgL}^{-1}$ respectively.

$\mathrm{Sn}=$ Recommended Federal Ministry of Environment permissible standard for the $\mathrm{n}^{\text {th }}$ water quality parameter.

The unit weight was calculated by a value inversely proportional to the recommended standard value $(\mathrm{Sn})$ of the corresponding parameter:

$\mathrm{Wn}=\mathrm{K} / \mathrm{Sn}$

Where:

Wn $=$ unit weight for the $\mathrm{n}^{\text {th }}$ parameters

$\mathrm{Sn}=$ standard value for the $\mathrm{n}^{\text {th }}$ parameters

$\mathrm{K}=$ proportionality constant

The proportionality constant $(\mathrm{K})$ was calculated by a value inversely proportional to the inverse of the aggregate of the recommended standard value for all the parameters used.

i.e. $K=1 / \sum(1 /$ Sn $)$

The overall water quality index was calculated by aggregating the quality rating with the unit weight linearly, such that:

$\mathrm{WQI}=\Sigma \mathrm{WnQn} / \Sigma \mathrm{Wn}$

\section{RESULTS}

\section{Physico-chemical Parameters of the Water Samples}

The result of the physico-chemical characteristics of the water samples collected from the various sources are presented in table 2. There was a distinct pattern in seasonal variations in the measured air and water temperature values. Air temperature values were always higher and they ranged from $21-31{ }^{\circ} \mathrm{C}$ to $23-31{ }^{\circ} \mathrm{C}$ across the study stations. Peak value was recorded in the dry season and lowest during the rainy season across the stations. There was no significant variation in the $\mathrm{pH}$ values recorded across the stations. The $\mathrm{pH}$ range of $4.2-6.8$ showed acidic trend regardless of seasonal variations. The conductivity values recorded in this study ranged from 7.2 to $196.0 \mu \mathrm{Scm}^{-1}$. Total dissolved solids mean values were quite below the standard values for drinking waters. Its mean concentrations were between $51.55 \mathrm{mgL}^{-1}$ at station 4 and $22.31 \mathrm{mgL}^{-1}$ at station 1 respectively. Dissolved oxygen mean concentration was lowest at station $1\left(9.37 \mathrm{mgL}^{-1}\right)$ and highest at station $5\left(13.29 \mathrm{mgL}^{-1}\right)$ throughout the study. Biochemical oxygen demand $\left(\mathrm{BOD}_{5}\right)$ recorded mean concentrations that were greater than $6 \mathrm{mgL}^{-1}$ when compared to the limit. The values were between $6.13 \mathrm{mgL}^{-1}$ and $9.47 \mathrm{mgL}^{-1}$ at stations 2 and 5. Chloride ions concentration in this study were far below the WHO and SON limits for drinking water. The mean concentrations varied from $30.62 \mathrm{mgL}^{-1}$ at station 4 to $51.98 \mathrm{mgL}^{-1}$ at station 1 . Salinity mean values were relatively high across the stations and had its range of values from $55.62 \mathrm{mgL}^{-1}$ at station 4 to $105.02 \mathrm{mgL}^{-1}$ at station 3. The overall nutrient concentration values were within the WHO and NIS limit for drinking waters.

Amongst the four heavy metals we investigated ( $\mathrm{Fe}, \mathrm{Zn}, \mathrm{Cu}$ and $\mathrm{Pb}$ ), it was only $\mathrm{Cu}$ that had its mean values across the study stations within the limits of WHO and NIS. Iron mean values were between 0.13 and $1.18 \mathrm{mgL}^{-1}$ at stations 3 and 2 respectively. $\mathrm{Zn}$ had its mean values ranging from $0.10 \mathrm{mgL}^{-1}$ at station 3 to $0.61 \mathrm{mgL}^{-1}$ at station 2 . The recorded mean values for lead was from 0.03 $\mathrm{mgL}^{-1}$ at stations 1,2 and 5 respectively to 0.08 $\mathrm{mgL}^{-1}$ at station 4 . 


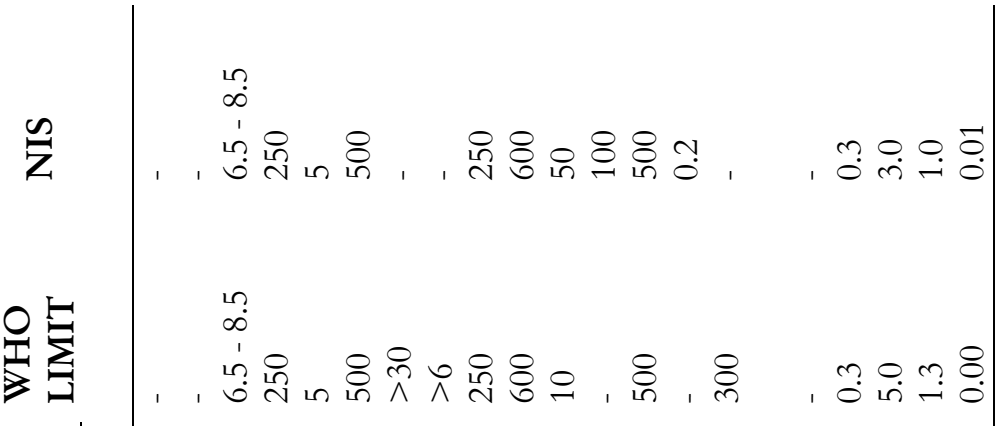

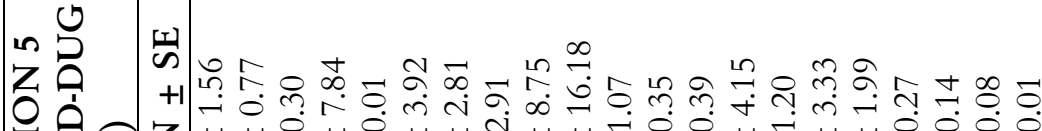

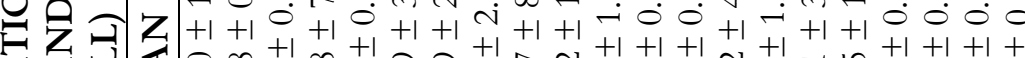

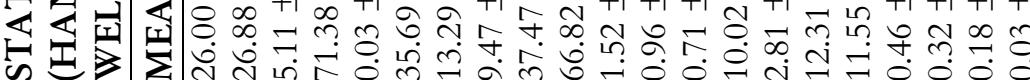

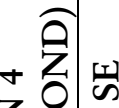

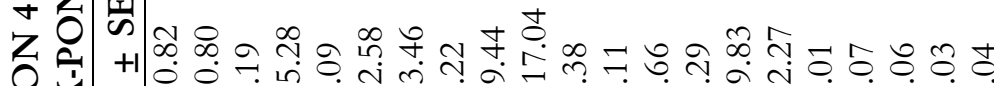

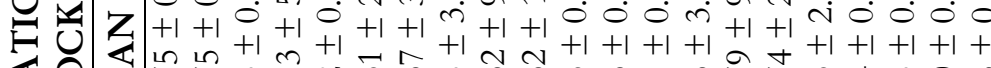

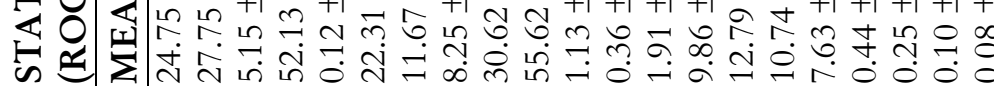

z

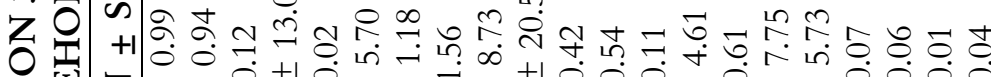

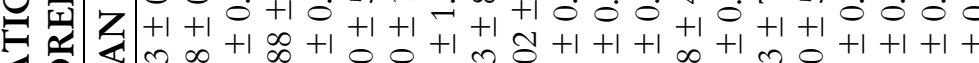
出 ž $\quad$ ज्ञ

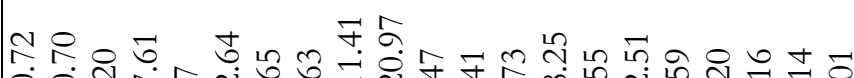

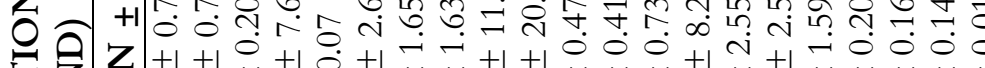

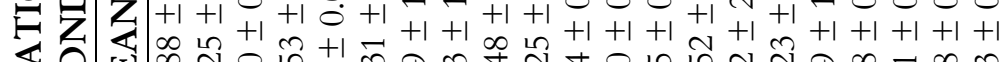

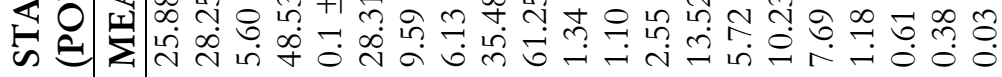

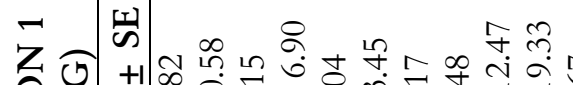

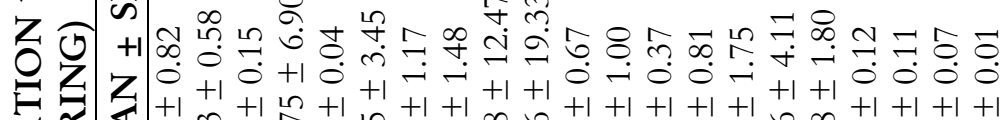

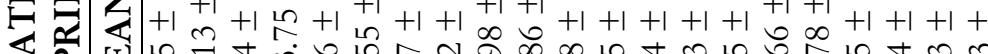

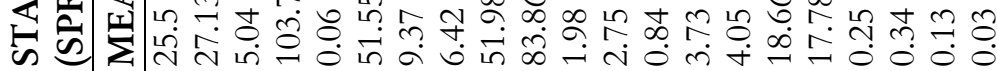
$\infty \infty \infty \infty \infty \infty \infty \infty \infty \infty \infty \infty \infty \infty \infty \infty \infty \infty \infty \infty$

点

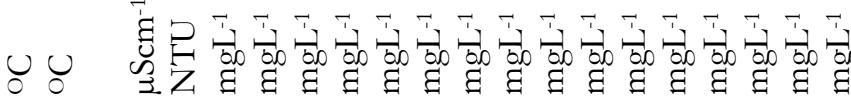


102 Lawani and Dirisu: Water Quality of Some Water Sources in Igarra and the Environs in Akoko - Edo

\section{Microbiological Parameters}

Mean microbiological counts of the investigated species are presented in table 3 . The mean total heterotrophic bacterial count (THBC) ranged in values from $3.625 \times 10^{3} \mathrm{CFU} \mathrm{ml}^{-1}$ at station 3 to $6.275 \times 10^{3} \mathrm{CFU} \mathrm{ml}^{-1}$ at station 5. Also the result of the total heterotrophic fungi count (THFC) varied from a low of $1.75 \times 10^{3} \mathrm{CFU} \mathrm{ml} \mathrm{m}^{-1}$ at station 3 to a high of $4.375 \times 10^{3} \mathrm{CFU} \mathrm{ml}^{-1}$ at station 5. Coliform bacteria count had values between $0.315 \mathrm{MPN}$ $100 \mathrm{ml}^{-1}$ (at station 3) and 1.64 MPN 100 $\mathrm{ml}^{-1}$ (at station 5). Still in the same trend, the lowest and highest values of $E$. coli (measured in MPN 100 $\mathrm{ml}^{-1}$ ) was from 0.139 at station 3 to 0.619 at station 5 . The mean values recorded for presumptive coliform, total heterotrophic bacteria and $E$. coli showed no significant difference $(P>0.05)$ across the stations. There was a significant difference $(P<0.05)$ in the total heterotrophic fungal count recorded. A posteriori DMR revealed that the spring and hand-dug wells were the source of significant differences observed.

Table 3: Mean Population Density Count of Bacteria and Fungi in Water from the Study Area

\begin{tabular}{lllllll}
\hline $\begin{array}{l}\text { Parameter } \\
\text { WHO }\end{array}$ & STN 1 & STN 2 & STN 3 & STN 4 & \multicolumn{2}{l}{ STN 5 } \\
\hline $\begin{array}{l}\text { THBC } \\
\text { CFUm- }\end{array}$ & $4.37 \times 10^{3}$ & $5.75 \times 10^{3}$ & $3.625 \times 10^{3}$ & $4.25 \times 10^{3}$ & $6.275 \times 10^{3}$ & 10 \\
$\begin{array}{l}\text { THFC } \\
\text { CFUml }\end{array}$ & $3.0 \times 10^{3}$ & $2.875 \times 10^{3}$ & $1.75 \times 10^{3}$ & $2.25 \times 10^{3}$ & $4.375 \times 10^{3}$ & 0 \\
$\begin{array}{l}\text { Coliform } \\
\text { MPN100ml }\end{array}$ & 0.774 & 1.144 & 0.315 & 0.395 & 1.64 & 0 \\
$\begin{array}{l}\text { E. coli } \\
\text { MPN100ml }\end{array}$ & 0.406 & 0.641 & 0.139 & 0.300 & 0.619 & 0 \\
\hline
\end{tabular}

Note: STN 1 to STN 5 implies stations 1 to 5 (as defined in Table 2 above).

\section{Water Quality Index}

A non-parametric analysis of variance for the water quality index revealed that there was no significant difference in the mean values recorded across the stations. The summary of the water quality index (Table 4) revealed that the mean values ranged from 349.59 - 1185.40. The overall water quality index as compared with WQI standard range showed that the water from the sampled stations were unsuitable for human consumption.

Table 4: Summary of the Mean WQI Values of the Sampled Stations

\begin{tabular}{llllll}
\hline Station & STN 1 & STN 2 & STN 3 & STN 4 & STN 5 \\
\hline Mean WQI & 349.59 & 571.04 & 1185.4 & 788.40 & 537.85 \\
Remark & Unsuitable & Unsuitable & Unsuitable & Unsuitable & Unsuitable \\
& for human & for human & for human & for human & for human \\
& consumption & consumption & consumption & consumption & consumption \\
\hline
\end{tabular}

Note: STN 1 to STN 5 implies stations 1 to 5 (as defined in Table 2 above).

\section{DISCUSSION}

The water quality of the stations was compared with the World Health Organisation (WHO, 2006) and Standard Organisation of Nigeria (SON, 2007) acceptable limits for drinking water.

The temperature of a water body is affected by a number of factors such as climate or temperature of the geographical area, extent of shade from direct sunlight and depth of the water (Ekhaise and Anyansi, 2005). Low pH values increases the corrosivity of water, the leaching of metal ions such as $\mathrm{Fe}, \mathrm{Mn}, \mathrm{Cu}, \mathrm{Pb}$, and $\mathrm{Zn}$ from the aquifer and the solubility of metals in water (USGS, 2015). 
The acidic $\mathrm{pH}$ recorded for water samples during the study were not within the WHO (2006) and SON (2007) acceptable limits for drinking water.

Conductivity is often affected by the geology of the area through which the water flows; however temperature and rainfall had been known to be a factor (APHA, 2005). The conductivity values recorded in this study ranged from 7.2 to 196.0 $\mu \mathrm{Scm}^{-1}$ across the study stations, and was similar to the findings by Adejuwon and Adelakun (2012) on the physico-chemical and bacteriological analysis of surface water in Ewekoro Local Government Area of Ogun State, Nigeria. The turbidity values were generally very low and were within acceptable limits of 5 NTU for drinking water. Freshwater water bodies with high coliform count would have a high BOD (Agbabiaka and Sule, 2010). This statement agreed with the BOD values in this study. Water samples with BOD less than 6 $\mathrm{mgL}^{-1}$ are considered clean. The BOD concentrations from this study depicts a high level of organic matter contamination; an indication of microbial contamination. The concentration of dissolved oxygen (DO) differed from the DO concentration obtained by Olomukoro and Oviojie (2014) on the physico-chemical characteristics and bacteriological studies in hand dug wells in Udu Community of Delta State, Nigeria. The total dissolved solids (TDS) values were in contrast to the findings by Adefemi (2013) on the physico-chemical and microbiological assessment of groundwater from Ijan-Ekiti, south western Nigeria. The salinity value was highest $\left(192.6 \mathrm{mgL}^{-1}\right)$ in the borehole water at Igarra town. The concentration of DO, TDS, turbidity and salinity were within the WHO and SON acceptable limits for drinking water.

Chloride is a widely distributed element in all rock types in one form or the other (Braide et al., 2004). Chloride concentration (10.23 - $\left.106.36 \mathrm{mgL}^{-1}\right)$ differed from the results obtained by Ojo and Agbede (2014) on Ikogosi Warm Spring Water in Ekiti State, south western Nigeria. The concentration of magnesium was above the permissible limit of $0.2 \mathrm{mgL}^{-1}$ and conferred hardness on the water. This corresponded to the results obtained by Abdullahi et al. (2013). The high magnesium concentration could be as a result of weathering of rocks and as such result in the hardness of water (USGS, 2015). The calcium values recorded in the study area were within the acceptable limits, and differed from the findings obtained by Adefemi (2013).

Nitrate concentrations were within the WHO acceptable limit for drinking water and corroborate the findings by Odeyemi et al. (2013). The concentration of phosphate was highest in the spring water $\left(7.32 \mathrm{mgL}^{-1}\right)$ and may be attributable to weathering of rocks rich in phosphate compounds around the spring; however, this also agreed with the findings of Onweluzo and Akaugbazie (2010) on the quality of bottled and sachet water sold in Nsukka town in Nigeria. The concentrations differed from the findings by Okonkwo et al. (2011) on the study of the Public Health Risk Status of the Water Supply Framework in Nsukka town and environs.

The concentration of chloride, nitrate, phosphate, sulphate and calcium were within the WHO permissible limits. Concentrations of trace metals were low in water samples compared to WHO and SON limits. The sources of zinc and other heavy metals in natural waters may be from geological rock weathering or from human activities such as industrial and domestic waste water discharges and animals where it forms constituent functions in maintaining cytoplasmic integrity (KoriSiakpere and Ubogu, 2008; Dirisu et al., 2017). The mean concentration of iron, zinc and copper in water were below the permissible limits of both the WHO and Nigerian standard for drinking water. The concentrations of $\mathrm{Zn}, \mathrm{Fe}$ and $\mathrm{Cu}$ agree with the findings of Denise et al. (2014) on concentration heavy metals in some water bodies in Eket and Nsit Ubium Local Government Area of Akwa Ibom State, Nigeria. The mean values of $\mathrm{Pb}$ were beyond permissible limit of $0.01 \mathrm{mgL}^{-1}$ in all stations and differed from the findings of Eze and Okeke (2012) on the analysis of heavy metal characteristics of tap and borehole water in Owerri, Nigeria. The concentrations of the heavy metal were significantly high throughout the study and are attributed to the rocky geology rich in the elemental mineral composition.

The water samples had mean bacterial and fungal 
counts that exceeded the WHO standards for drinking water (Table 3). This level of microbial contamination is in agreement with the results obtained by Nwachuckwu and Ume (2013) on the bacteriological and physicochemical qualities of drinking water sources in eastern Nigeria. The spring water, pond and rock-pond are surface water bodies that are exposed to intense anthropogenic contamination. In one of the sites, the hand-dug well is located less than 20 meters to a pit toilet. The higher number of bacterial count recorded in spring water, pond and rock pond samples could probably be as a result of the increased surface area which exposes the water to contaminants as well as other human activities (Manjula et al., 2011). Peak microbial counts were obtained during the rainy season which is strongly attributed to the deposition from eroded matter.

The application of water quality index (WQI) in this study has been profoundly useful in the assessment of the overall quality of the water sources. The WQI of the water samples (349.59, $571.04,1185.39,788.40$ and 537.85) from the various water sources, and the overall water quality index (686.456) were not within the permissible limits for the entire samples taken in this study. This was an indication that the water from the selected sources in the study area could be categorized as unsuitable for human consumption.

\section{CONCLUSION}

In conclusion, the physicochemical analyses of ground and surface waters in the study area revealed high levels of, $\mathrm{BOD}, \mathrm{DO}$, acidic $\mathrm{pH}$, iron and lead, which were beyond the WHO permissible limits for drinking water. Microbiological analysis of the samples showed microbial contamination beyond acceptable standards for drinking water in Nigeria. The overall water quality index (WQI) revealed that the water analysed were unfit for human consumption. Ground water sources should be located at least 30 meters away from septic tanks/pits to reduce microbial contamination, and natural surface water sources should be protected against uncontrolled anthropogenic activities. There's an urgent need for the provision of safe drinking water sources for rural communities and towns in Akoko-Edo to maintain good public health.

\section{REFERENCES}

Abdullahi, M., Saidu, B.T., Salihu, B.A. and Mohammed, S.A. 2013. Bacterological and physico-chemical properties of borehole water in Niger State Polytechnic, Zungeru Campus. Indian Journal for Scientific Research, 4 (1): 1 - 6.

Adefemi, S.O. 2013. Physicochemical and Microbiological Assessment of Groundwater from Ijan-Ekiti, South western Nigeria. Swiss Journal of Applied Sciences. 2(5): 13 - 21.

Adejuwon, J.O. and Adelakun, M.A. 2012. Physiochemical and bacteriological analysis of surface water in Ewekoro Local Government Area of Ogun State, Nigeria: Case study of Lala, Yobo and Agodo Rivers. International Journal of Water Resources and Environmental Engineering, 4(3): 66-72.

Agbabiaka, T.O. and Sule, I.O. 2010. Bacteriological assessment of selected borehole water samples in Ilorin metropolis. International Journal of Applied Biological Research, 2(2): 31 - 37.

Akpoveta, O.V., Egharevba, F. and Medjor, O.W. 2011. A pilot study on the biodegradation of hydrocarbon and its kinetics on kerosene simulate soil. International Journal of Environmental Sciences, 2(1): 1 - 14.

APHA, (American Public Health Association) 2005. Standard methods for the examination of water and wastewater. 21 st edition, Eaton, A.D., Clesceri, L.S., Rice, E.W., Greenberg, A.E., Franson

Braide, S.A., Adiukwu, P.U., Chindah, A.C., Izonfuo, W.A.L. and Obunwo, C.C. 2004. Water quality of Miniweja stream, a swamp forest stream receiving non-point source waste discharges in Eastern Niger Delta, Nigeria. Scientia Africana, 3(2): 1 8.

Cude, C. 2001. Oregon water quality index: A tool for Evaluating Water Quality Management Effectiveness. Journal of American Water Resources Association, 37(1):125-137. 
Lawani and Dirisu: Water Quality of Some Water Sources in Igarra and the Environs in Akoko - Edo

Denise, E.M., Idada, I. and Udoh, E.I. 2014. Comparative Study of Heavy metals concentration in some water bodies in EKET and NSIT Ubium local government area of Akwa Ibom State, Nigeria. Advances in Applied Science Research, 5(3): 1 - 4.

Dirisu, A.R. and Olomukoro, J.O. 2015. Investigation of water quality of two Rivers in Agbede wetlands in Southern Nigeria. Global NEST Journal, 17(3): 451-462.

Dirisu, A.R., Olomukoro, J.O. and Ezenwa, I.M. 2017. Physico-chemical trends in the

sediments of Agbede wetlands, Nigeria. Materials and Geoenvironment, 64: 35 - 50. DOI 10.1515/rmzmag-2017-0003

Edema, M.O., Fapetu, O.M. and Omemu, A.M. 2001. Microbiology and physico-chemical analysis of different sources of drinking water in Abeokuta South L.G.A., Ogun State. Nigeria Journal of Microbiology, 15(1): $57-61$.

Ekhaise, F.O. and Anyansi, C.C.. 2005. Influence of brewery effluent discharge on the microbiological and physicochemical quality of Ikpoba River, Nigeria. African Journal Biotechnology, 4(10): 1062 - 1065.

Eze, V.C. and Okeke, C.O. 2012. Comparative analysis of microbiological and heavy metal characteristics of tap and borehole water in Owerri, Imo State, Nigeria. Journal of Research in Public Health. $1(2): 47-55$.

Kori-Siakpere, O., Ubogu E.O. 2008. Sublethal haematological effects of Zinc on the

Freshwater fish, Heteroclarias sp. (Osteichthyes: Clariidae). Afr. J. Biotechnol., 7(12): 20682073.

Manjula, A.V., Preeti, S.M. and Shankar, G.K. 2011. Bacteriological analysis of drinking water samples. Journal of Bioscience Technology, 2(1): 220 - 222.

Nigerian Industrial Standard. 2007. Standards Organisation of Nigeria. NIS 554; Nigerian Standard for Drinking Water Quality. Pp 30

Nwachuckwu, E. and Ume, C.A. 2013. Bacteriological and physicochemical qualities of drinking water sources in
Eastern Nigeria. Journal of Environmental Science and Water Resources, 2(9): 336 - 341.

Odeyemi, A.T., Adebayo, A.A. and Adeosun, O.M. 2013. Bacteriological and physicochemical Studies on three major dams in Ekiti State, Nigeria. Journal of Environment and Earth Science, 3(7): $210-218$

Okonko, I.O., Adejoje, O.D., Fajobi, E., Ogunnusi, T.A. and Shittu, O.B. 2008. Microbiological and physicochemical analysis of different water samples used for domestic purposes in Abeokuta and Ojota, Lagos, Nigeria. African Journal of Biotechnology, 7 (5), 617 - 672.

Okonkwo, C.J.O., Okonkwo, T.J.N. and Okoria, O. 2011. Public health risk status of the water supply framework at Kwame Nkrumah (Postgraduate) Hall, University of Nigeria, Nsukka and environs. African Journal of Environmental Science and Technology, 5 (7): 522 - 529.

Ojo, O.M. and Agbede, O.A. 2014. Assessment of Ikogosi warm spring water quality in Ekiti State, south western Nigeria. Sci-Afric Journal of Scientific Issues, Research and Essays, 2(3): 116-123.

Olomukoro, J.O. and Oviojie, E.O. 2014. Physicochemical characteristics and bacteriological studies in hand dug wells in Udu community of Delta State, Nigeria. Journal of Environment and Earth Science, 4(22): 116- 120.

Onuh, J.O. and Isaac, V.U. 2009. Physicochemical and microbiological quality of water sources from some major towns in Igala land. Nigeria Food Journal, 27(22): 66 72.

Onweluzo, J.C. and Akaugbazie, C.A. 2010. Assessment of the quality of bottled and sachet water sold in Nsukka town. Journal of Tropical Agriculture, Food, Environment and Extension, 9(2): 104 110.

USGS, 2015. United States Geological Survey. Science for a changing world. Available at https://water.usgs.gov/edu/mwater.htm 1. Accessed on 18th March, 2015. 
106 Lawani and Dirisu: Water Quality of Some Water Sources in Igarra and the Environs in Akoko - Edo

WHO, 2006. World Health Organization. Yisa, J. and Jimoh, T. 2010. Analytical studies on Guidelines for drinking water quality. Incorporating first addendum: Vol. 1recommendations: $4^{\text {th }}$ edition, Geneva. water quality index of River Landzu. American Journal of Applied Sciences, 7(4): $453-458$. 